\title{
An Analysis of Motivational Actions Used by the Lecturers in Teaching Reading to Motivate the Students of Syariah Faculty at IAIN STS Jambi
}

\author{
Yenti \\ Language Education Program, State University of Padang \\ yentialkamar@gmail.com
}

\begin{abstract}
ABSTRAK
Artikel ini ditulis untuk mengetahui tindakan memotivasi yang digunakan oleh para dosen dalam pengajaran membaca Bahasa Inggris di Fakultas Syariah IAIN STS Jambi. Penelitian ini dilakukan terhadap mahasiswa tahun pertama. Jenis penelitian adalah descriptive dengan menggunakan teknik observasi dan wawancara tertulis. Sumber datanya dari semua kegiatan belajar mengajar yang dilakukan oleh para dosen Bahasa Inggris. Hasil penelitian menunjukkan bahwa para dosen bahasa Inggris di fakultas Syariah hanya menerapkan enam dari tujuh jenis indikator untuk tindakan memotivasi mahasiswa, yaitu menggunakan alat dan media sebagai alat bantu, memberikan pujian, membangun suasana santai, memberikan kesempatan kepada para pelajar untuk membaca, memberikan contoh positif. Membangun pengetahuan mahasiswa tidak diaplikasikan oleh dosen bahasa Inggris dalam pengajaran membaca. Hasil dari riset, dapat dijelaskan bahwa semua mahasiswa termotivasi ketika para dosen mereka menggunakan tindakan motivasi dalam mengajar bahasa Inggris.
\end{abstract}

Kata Kunci:

motivasi, belajar membaca, fakultas syariah

\section{INTRODUCTION}

Reading is one of the four skills that require the students to interpret the written or printed text and to get some understanding about information and knowledge. The lecturers have big roles to bring these concepts into practice, such as; asking students to read more text books, asking them to memorize some words in order to enlarge their vocabularies. By reading, students will get much information to expand their knowledge into reality. Today, there are many books and references written in English. In order to inform this knowledge as much as possible, the students have to be able to read efficiently and effectively in their learning process. Brown (2002: 124) argues reading is the most essential skills for success in all educational contexts. It indicates that reading skill gives important contribution to students' success in learning because of reading; they can get much information to face this life in their future time.

Although reading is an activity which can develop English ability, every student does not show their interest to read text books. They tend to be passive and have no initiative to read more reading books. Educators and scholars agree that motivation is crucial in language teaching. Students who have good and high motivation will get more knowledge and skills in their life. Motivation is a desire or willingness to do something. Brown (2002; 134) says motivation is one of the most important factors for success in English. Some people are very strongly motivated to learn a language. It means that everyone has different reasons and purposes in learning something.

Based on the researcher's experience with some students at the first level at Syariah
Faculty of IAIN STS Jambi, from 40 students in two classes, there were 20 students cannot read the text fluently and perfectly. And some of them do not have motivation in teaching reading English in the classroom.

The researcher assumes that this condition may be caused by several problems. The first problem is many of the students are lack of vocabulary. It is impossible to the students to understand the text well if they do not have enough vocabularies.

The second problem is that some of them cannot read the text fluently, because the students never practice reading much before. They read a text slowly and often stopped reading if the content of the text was too long.

The third problem is that the lecturers' strategy in teaching reading. The lecturers teach the students classically in which the lecturers ask the students to read the entire page by reading text loudly either individually or by taking turns.

The last problem is that some of their text books are printed in English. So, they have to read the text books. They do not have motivation in reading. They are too lazy to look up their dictionaries to find the meaning.

Therefore, motivation is very important to make the students able to study and learn English. The students who have high motivation have much interest and attention to the learning process. Moreover, they are more creative and serious in learning English.

Based on the situation above, the lecturers need to find a good way to teach their students. One of the way is to give motivational actions in their class while they are teaching. There are sort of motivational actions that can be applied in teaching and learning process such as 
telling a story, giving praise, giving direct reward, playing games, and many others which may help them to motivate the students to improve their reading skills.

A motivational action is an action or a way which is used by the lecturers to motivate their students to study English in teaching English. Schunck, et al (2008) explains that there are several actions to motivate students in learning: (1) telling a story, (2) using visual aids, (3) building a fun situation, (4) giving praise, (5) building students' confidence and self esteem, (6) playing games.

In telling a story, many students are responding to narratives rather than facts which it has been linked together. The human interest or story behind the events makes things more interesting and encourages students to pay attention to the topics they want to disregard.

Giving visual aids can be a great way to show the students how a concept works. One of them is media. Media can make the teacher's job easier. It can bring the material needed in learning and facilitate the students to search information and data given.

More, in making a fun situation will make the students enjoy and relax. In relaxing situation, the students can study everything. So, the teachers have to make a good atmosphere in their class.

Then, the lecturers can give some praises when a student does a good job, although their students make many mistakes. By giving praise, it makes the students be happy in doing something.

Using feedback and conversations mean to build up their self esteem, confidence and sense of self-worth. It can motivate the students to do something well.

Lastly, playing games will encourage the students to do what they put in their minds to. Games can be applied in teaching learning English. This idea supported by Wright, Betterridge and Buckby (1998:245) states that games can be found to give practice in all skills (reading, speaking, listening and writing).

Moreover, Uno (2011) explains some ways to motivate students in classroom: (1) direct rewards, (2) build students' knowledge, (3) give surprise, (4) use simulation and play, (5) giving chance to show their ability, and (6) give a positive example.

Giving direct rewards to the students is the easiest and effective way to motivate students in learning. The teachers or the lecturers may give rewards inform of extra point for every students.

Building students' knowledge is another way to motivate the students. The teacher or the lecturer can create a good situation and condition which is not imagined by the student yet.

More, giving a surprise is another way to motivate the students to study the lesson. The lecturers have to give something different from another. They can give some games or quiz in teaching English.

Then, simulation and play are interesting processes by the students. It can make the students be enjoy and happy in studying the lesson. They can create a new thing in studying.

Next, in giving chance, the teachers ask the students one by one to do something in their chair or in front of their friends, give them same opportunity. Let them to show their ability in front of their students.

Finally, give positive example is another way to make the students to study. It is not enough if the teachers give only task, they should control and accompany the students in doing task. They have to care about their students when their students are doing exercise in the classroom.

In doing this research, the researcher used the theories. They are; using a visual aid, giving praise, building a fun situation, giving a direct reward, giving a chance to show their ability, building student's knowledge and giving a positive example.

Based on those explanations, the purposes of the research are:

1. To describe what motivational actions are used by the English lecturers in teaching reading.

2. To describe how the lecturers apply motivational actions in teaching reading.

3. To find out to what extent are the students motivated by the lecturers' motivational actions in teaching reading.

\section{METHOD}

This research was classified into descriptive research. The purpose of descriptive research was to gain information about phenomenon in order to describe the existed condition in the field. It is suitable to explore and describe the nature of the research field. Gay and Airasian (2002:156) say that the descriptive study determines and describes the way of they are. Here, the research only focused to analyze and observe the motivational actions used by the lecturers in teaching reading English and learning process in the classroom.

This study was conducted at Syariah faculty of IAIN STS Jambi. It was located at Jambi-Muaro Bulian Street KM 16 Duren river junction Jambi.

The population of this research was all of English lecturers who taught English in the first year grade at Syariah faculty at IAIN STS Jambi and all their students who studied English with 
them. They were the center of the data and the target of analysis. There were seven lecturers and 120 students to be observed and analyzed in this research. The data of this research were information that related to the motivational actions used and applied by the English lecturers in teaching reading. The data were taken by using handy cam to make observation in the classroom where the lecturers taught reading. Sources of the data were lecturers and the activities of teaching and learning process. Observations were conducted three times for every class.

Table 1. Kinds of motivational actions used in the classroom

\begin{tabular}{|c|c|c|c|c|c|c|c|c|}
\hline \multirow[t]{2}{*}{ No } & \multirow{2}{*}{ Kinds of Motivational } & \multicolumn{7}{|c|}{ Lecturers } \\
\hline & & First & Second & Third & Fourth & Fifth & Sixth & Seventh \\
\hline 1 & Using a visual aids & $\mathrm{v}$ & - & - & - & v & - & - \\
\hline 2 & Giving a praise & $\mathrm{v}$ & $\mathrm{v}$ & - & - & $\mathrm{v}$ & $\mathrm{v}$ & - \\
\hline 3 & Building a fun situation & $\mathrm{v}$ & - & - & - & $\mathrm{v}$ & - & - \\
\hline 4 & Giving chance to read & - & v & $\mathrm{v}$ & $\mathrm{v}$ & $\mathrm{v}$ & $\mathrm{v}$ & v \\
\hline 5 & Giving direct rewards & - & - & - & v & $\mathrm{v}$ & - & - \\
\hline 6 & Building students knowledge & - & - & - & - & - & - & - \\
\hline 7 & Giving positive example & $\mathrm{v}$ & $\mathrm{v}$ & $\mathrm{v}$ & $\mathrm{v}$ & $\mathrm{v}$ & $\mathrm{v}$ & v \\
\hline
\end{tabular}

\section{FINDINGS AND DISCUSSIONS Findings \\ Types of Motivational Actions}

Based on the table above, it can be concluded that using visual aids were applied by two lecturers, the first lecturer and the fifth lecturer, in their teaching reading English in classroom. Giving praise was often applied and used by four lecturers in teaching reading English in the classroom. They were first lecturer, second lecturer, fifth lecturer, and sixth lecturer. Building fun situation was only used by two lecturers in their teaching reading in the classroom. They were first lecturer and fifth lecturer. Almost of the English lecturers applied giving chance to read to their students in teaching reading English in their classroom. Only one of them did not use it, it was the first lecturer. There were two lecturers who applied giving direct reward directly to their students, the fourth lecturer and the fifth lecturer. All the English lecturers applied giving positive example in their teaching reading English in the classroom. And finally, only one kind of motivational actions was not applied by the English lecturers, it was building student's knowledge.

From the explanation, it could be concluded that only two lecturers who applied five kinds of motivational actions in their teaching reading in the classroom, the first lecturer and the fifth lecturer. Giving positive example was applied by all the lecturers in their teaching reading. Building student's knowledge did not use optimally by the English lecturers in their teaching reading English in the classroom.

\section{The Ways of Applying Motivational Actions}

To apply the using of visual aids, the lecturers used in focus as their media in their teaching English. They used it to show their material in explaining the subject. It could make the students easy and understand the lesson. They also used some interesting pictures and text to their students by using in focus. It could make the students interested.

Furthermore, in applying giving praise to the students, the lecturers used expressions of the words and sometimes they kept smiling to the students if the students made good things. The expressions of the words which often used by the lecturers in teaching reading by saying "good", "very good", "ok", "excellent", "well done". It also could motivate the students to study reading English.

After that, in building fun situation in classroom, the lecturers made the classroom fun and relax. They always made some jokes when they taught their students. The students can study reading English easy and it never made them be bored and lazy.

Then, in giving chance to read or opportunities for the students in studying reading English, the lecturers gave the chance to the students to read one by one in front of the class or only sat on their chairs and sometimes they asked them to translate the text one by one.

Next, in applying giving direct rewards, the lecturers used point book to give extra point directly in front of the students. They asked the students to read after that they gave mark. They became seriously, because they knew that they had to be able to read the text fluently if they wanted to get good point from their lecturer.

Finally, to apply positive example, the lecturers used expressions by accompanying and guiding the students in doing the exercise, and they corrected the mistaken word if the students read the text. The students felt that they were paid attention by their lecturers.

Based on the observation, all of the English lecturers at Syariah Faculty at IAIN Jambi did not give the motivational actions optimally to the students. They did not use motivational action in their teaching English. Few of them used motivational actions. But they did not know exactly about motivational actions. They applied it because they have to use it in 
their teaching English. They never want to motivate their students to study,

\section{Describing to what extent the students are motivated by the lecturers' motivational actions.}

In analyzing the third research questions, the researcher did observation and gave the interview guide to the students to know whether they were motivated when their lecturers taught reading by application of the motivational actions in the classroom. The students could write the answers directly on the paper sheets. It was an open interviewing. Before they answered the questions, the researcher explained all of the questions, because not all of the students understood the questions.

\section{Discussions}

\section{The Kinds of Motivational Actions}

The first lecturer applied four kinds of motivational actions in his teaching reading. They were using visual aids, giving praise, building fun situation, giving positive example. He used laptop and in focus to present material in front of the students. It was supported by (Smart Teaching, 2010). He states that the lecturers bring the visual aids into the class and used it to show the students about the topic what they would learn on that day. It could make the students easy and understand the lesson. $\mathrm{He}$ gave more praises to his students when they made some good things in reading or answering the questions. He always made a joke in his teaching. The situation of the classroom could make the students be relax and funny. This is supported by Smart Teaching (2010). Fun situation makes the students seem more like fun than work and it can engage even the most reluctant of the students. Every student had big spirit and motivation in the class. He also gave positive example to his students by guiding them to find the correct answer.

The second lecturer only applied three kinds of motivational actions in her teaching. Those were; giving praise, giving chance for students to read and giving positive example. In giving praise, she only gave four praises to her students. She also gave chance to her students to read the text. She asked them to read one by one on their chair. She also gave positive example by accompanying them to correct their mistaken words. Uno (2011) explains that by giving the students positive example, by doing controlling and accompanying. It will motivate the students to do exercise and practice.

The third lecturer applied two kinds of motivational actions in her teaching reading in the classroom; gave chance to the students to read the text one by one and gave positive example by helping them to correct the mistaken words. She only sat on her chair while the students did their exercise.

Furthermore, the fourth lecturer used three kinds of motivational actions. Those were; gave chance to read the text one by one, gave direct rewards and gave positive example. She asked her students to read the text in front of her. She called them two by two to sit on the chair and after that, she gave direct rewards. She directly gave point in her book. Huitt (2001) states that one ways to give motivation to the students in the classroom is by giving rewards to them. All of the students were motivated when their lecturer gave point on her result book. It was found direct reward had positive effect in motivating the students to read. As stated by Uno (2011) direct reward is one of technique of teaching enable to motivate the students to learn. The lecturer had applied it optimally. On the other side, this technique also has weaknesses. The weaknesses were the students only wanted to read when the lecturer took her result book. If the students made mistake in their reading, the lecturer corrected it.

Next, the fifth lecturer had applied five kinds of motivational actions in her teaching reading. They were: using visual aids, giving praise, building fun situation, giving chance or opportunities for students to read, giving direct rewards, giving positive example. She was an interesting lecturer. Firstly, she prepared all of the materials. She used laptop, in focus. She brought some pictures into the classroom. Schunk et al (2008) explain that there are some techniques that can be used by the teacher in the classroom. They are; specifying learning objectives, select activities and use visual aids. They also explain that visual aid will help the students in learning because they are invited to ask related to the pictures or video given. The lecturer also gave some praises to the students if they made good things. She could make fun situation in every time, it made the students be happy and relax. As stated by Hedge (2000) motivations have high correlation with students successful in learning, it is crucial importance in the classroom. So, the teacher had given good motivational actions in teaching reading in the class.

Then, the sixth lecturer used three kinds of motivational actions. Giving praises, giving chance to read, giving positive example. She always gave some praises to the students if they could answer the questions. She asked them to make some groups. After that, she asked group per group to read the text. And she also gave positive example to the students by accompanying the students to do the task.

Finally, the seventh lecturer used two kinds of motivational actions. They were giving chance or opportunities to the students to read 
the text and giving positive example. He didn't use visual aid and never gave praise to his students. After reading the text, he asked the students to read the text and gave positive example by correcting the mistaken words. The situation of the class was very noise. He let the students to make noise while he was explaining the lesson.

\section{The Ways of Applying Motivational Actions}

From the observation, it was gotten that some of the English lecturers at IAIN STS Jambi didn't use motivational actions in teaching reading and they did not know how to motivate their students. They only knew the meaning of motivational action was, but they did not know how to apply and use it in teaching reading English.

Actually, motivational actions should be always given to the students because it would motivate the students to read English in the classroom. Hedge (2000:23) explains that motivation has high correlation with students successful in learning.

It was supported by Yuan Kong (2009:146) motivation is not only an intensive desire for learning and acquiring knowledge of language, but also inner caused that push students forward in the language learning enthusiasm and willingness.

The lecturers did not use and apply the motivational actions optimally in their teaching reading. It was caused by the lecturers did not know and understand how to use and apply motivational actions in teaching reading. During teaching reading, the lecturers only explained the material and asked them to read the text. They used traditional ways, and did not want to give motivation to their students. As stated by Schunk et al (2008:300) in the interaction with students, lecturers can structure classroom events to have powerful effect on students' motivation.

Finally, it could be concluded that some of the lecturers at IAIN STS Jambi seemed to be effortless to motivate their students in teaching reading. It was caused because they did not know exactly about the concepts of motivational actions, they just knew about the words of motivation but they did not know how to apply it.

\section{Describing to what extent the students are motivated by the lecturers' motivational actions.}

It was found that some of the students were not motivated when their lecturers taught reading English because of some factors. They were the materials, the situation of the class, lack equipments, and lack motivation. Some of lecturers never gave praise to them if they made good things and besides, the lecturers never used visual aids in teaching reading English.

Moreover, they also never made some jokes in the classroom, it became the situation of the classroom was serious and the learning process run too slow and silent. They let their students studied by themselves. The lecturers never wanted to make the class became relax. The lecturers only did their duties as a lecturer. Nevertheless, some of the English lecturers at IAIN STS Jambi didn't do like that. Only one or two of them did motivational actions optimally in their teaching reading. They used visual aids and gave some of the motivational actions to their students. And the others did not apply them to their students. They only knew the meaning of motivation, but they did not know how to apply and use it to their students. Actually, some of the lecturers did motivation to their students, but they did not know the motivational action was exactly. They used and applied motivational actions in their teaching reading because they only wanted to use it in teaching reading.

\section{CONCLUSION}

1. There were seven indicators used and applied in teaching reading English in the classroom. They were: Using a visual aids, giving a praise, building a fun situation, giving chance to read, giving direct reward, giving positive example and building knowledge. Only six of them can be applied and used optimally in teaching reading English. The indicator of building students' knowledge was not used by all of the lecturers.

2. In applying motivational actions in the classroom, the lecturers used media and expressions. To apply the using of visual aids, the lecturers used in focus, pictures and some texts. In giving a praise to the students, the lecturers used some expressions of words. Example: good, very good, ok, excellent, well done. In building a fun situation in the classroom, the lecturers made the classroom relax and fun. They made some jokes when they taught their students. To give a chance for the students to read English, the lecturers asked the students to read one by one in front of the class or only sat on their chairs. Next, to apply giving direct rewards, the lecturers used point book to give an extra point directly in front of the students. Finally, to apply positive example, the lecturers accompanying and guiding the students in doing the exercise and they corrected the mistaken words if the students read the text.

3. The students were motivated in studying reading English when the lecturers applied and used motivational actions in teaching reading English. They wanted their lecturers 
always used visual aids, giving praise, direct rewards in their teaching reading English. They were also given chance to read the text, because they wanted to know they can read text perfectly or not.

\section{BIBLIOGRAPHY}

Brown. H Douglas. 2000. Teaching by Principles: An Interactive Approach to Language Pedagogy. $\left(2^{\text {nd }}\right)$ London: Longman.

Gay, L., R. and Peter Airasian. 2000. Educational Research: Competencies for Analysis and Application. New Jersey: Prentice Hall, Inc.

Hedge, Tricia. 2008. Teaching and Learning in Language Classroom. New York: Oxford University Press.

Huitt, W. 2001. Teaching and Learning in Language classroom, Educational Psychological.

Schunck, Dale H. et. al 2008. Motivation in Education: Theory, Research, and Application. $3^{\text {rd }}$. Ed. New Jersey: Pearson Education, Inc.

Inc Uno, B. Hamzah. 2010.Teori Motivasi dan Pengukurannya. Jakarta : PT. Bumi Aksara.

Wright, A., Betterridge, D., \& Buckby, M. 1984. Games for Language Learning. Cambridge University Press.

Yuan Kong.2009. A Brief Discussion on Motivation and Ways to Motivate Students in English Language Learning.www.ccsenet. org/journal.html. 